\title{
Nursing - problems with its position in the health care system
}

\author{
Maria Kózka
}

Zakład Pielęgniarstwa Klinicznego, Instytut Pielęgniarstwa i Położnictwa, Wydział Nauk o Zdrowiu, Uniwersytet Jagielloński Collegium Medicum, Konsultant Krajowy w dziedzinie pielęgniarstwa

Address for correspondence: Maria Kózka, Zakład Pielęgniarstwa Klinicznego, Instytut Pielęgniarstwa i Położnictwa, Wydział Nauk o Zdrowiu, Uniwersytet Jagielloński Collegium Medicum, 31-501 Kraków, ul. Kopernika 25, maria.kozka@uj.edu.pl

\section{Abstract}

Nurses, the bulk of health care staff, provide care for people of any age, family, group and community backgrounds, the sick and the healthy coming from different environments. Although recognised as an autonomous medical profession, they do not occupy the right position in the health care system. According to the International Council of Nurses (ICN), nurses can have a significant influence on the efficiency and effectiveness of the entire health care system by performing various tasks and making daily decisions within the framework of executing professional practice. They can also have an important contribution to the process of planning health care, making decisions and the development of effective policy within health care. However, it requires meeting certain conditions, which should include: efficient and well-managed health care system, proper financing system of health services, clearly defined competences of nurses, access to modern methods of care, and also the size of qualified and motivated personnel. This paper presents the problems with the position of nursing in the health care system considering different conditions.

Key worls: health care system, nursing, nurse

Stowa kluczowe: pielegniarka, pielegniarstwo, system opieki zurowotnej

\section{Introduction}

Vocational nursing has a relatively short history that started in the second half of the twentieth century [1]. Its beginning is said to be marked by the establishment of the first secular nursing school at the London St. Thomas' Hospital in 1860. The coordinator of the school and author of its programme and learning concept was Florence Nightingale. Only unmarried women were admitted to the school. At the beginning it prepared nurses to care for the sick in the hospital as well as perform simple procedures ordered by the doctor. The model of vocational training introduced by Florence Nightingale became implemented in Europe, the United States and Canada. Vocational training led to the identification of the nursing profession, considered to be doctor's aid [1].

The development of nursing around the world was diverse and closely linked to the socio-economic and political changes of individual countries, and had a significant impact on the health care and nursing care of their inhabitants. An important moment for the development of the profession was the creation of the International Council of Nurses (ICN) in the United States in 1899. ${ }^{1}$

The changes introduced in nursing education programmes and practices, as well as research done by representatives of this professional group, played a significant role in enhancing its prestige and strengthening its professional position. North American nurses played a leading role in this issue, starting their higher-level education as early as in the 1920s [1].

Nowadays, nurses are the largest group of health care professionals, providing care to people of all ages, both sick and healthy. Despite the fact that under the Act on Nursing and Midwifery Professions of 5 July 1996 and the new Act of 15 July 2011, ${ }^{2}$ the nursing profession is 
autonomous [2] - it does not occupy the right position in the health care system.

According to A. Bajtor: "Nurses are increasingly well-qualified and at the same time are taking on more and more tasks; they are striving to occupy the right position and achieve an adequate status in the hierarchy of medical professions. Despite that, they are neither recognized nor respected by their colleagues, or the wider public (public opinion). The status of nurses - their place, role and position in the division of labour - does not significantly change once they have completed higher education" [3, p. 329]. A similar stance is taken by the International Council of Nurses [ICN], which believes that nurses around the world continue to face difficulties in how they are positioned in the context of the health care system, although the type and degree of problems varies. The organization also points out that the nursing staff is an economically efficient, undervalued and poorly utilized resource in health care $[4,5]$.

Participants in the recent ICN-World Bank meeting noted that nurses are being used below optimal levels of health care, management and policy making, and are not being utilized to the full extent of their capacity [6]. According to the WHO report, nurses have an impact on improving the health of the population and the overall level of effectiveness of health care provision [7]. This position is validated by well-documented research results showing the benefits of nurses' interventions [8,9]. In 32 studies carried out in the OECD -which included three strategic nursing areas: psychiatric care, chronic illness and change of competencies - the measurable benefits of nursing, preventive care and treatment were calculated. In another study, the risk of cardiovascular disease was shown to be reduced as a result of the educational activities undertaken by nurses [10].

Recognizing the need to provide more patients with access to care and to reduce costs, nurses in many countries have been given new powers, such as issuing prescriptions and orders for selected tests, ${ }^{3}$ which has produced expected results $[11,12]$.

Despite the changes that have taken place in recent years regarding the position of nurses in primary care (Polish: POZ), their role is still limited in most countries. Studies by Kringos et al. [13] have shown that only 12 countries (out of 31 analyzed) are involved in health education in primary care, and even fewer - only five run diabetes care centres. However, many countries are aiming to involve nurses in a closer collaboration with physicians. This tendency is especially noticeable in Denmark, Poland, the Netherlands, and Sweden [14]. Currently, nurses can provide autonomous care to patients with lighter illnesses in England and Sweden, prescribe medication in England, Poland, Romania and Sweden (but the range of medications prescribed is strictly limited). In England and the Netherlands, nurses can provide health programmes such as vaccination for children and adolescents. In addition, nurses in some countries (Belgium, Denmark, England, Finland, Poland, Slovenia and Sweden) are increasingly put in charge of coordinating the transport of patients with chronic diseases. Sweden was one of the first European countries to set up clinics for patients with chronic diseases such as diabetes, asthma, chronic obstructive pulmonary disease or heart failure, as an alternative method to support outpatient treatment after acute illness. Such clinics are currently operating also in Denmark, England, Estonia, France and two regions of Spain - Andalusia and Catalonia [14].

On the one hand, nursing is a cost-effective profession, on the other - it is underestimated and not fully utilized in the health care system.

The aim of this article is to present the key determinants that influence the position of nursing in the health care system.

The article is based on an analysis of global and national conditions which are of prime interest to the authors of publications and reports. With regard to global conditions, the focus was on the lack of or limited influence of nurses on health policy, the feminization of the profession, medicalization and financing of health care, the shortage of nurses and the conditions of their work, while the national character of vocational training was presented through the historical context of vocational training, legal regulations and the scope of leadership.

The author of the paper is convinced that it is not an exhaustive presentation of all possible conditions and can be an inspiration for further analysis.

\section{Global conditions}

The literature distinguishes global problems that have significant implications for the development of nursing and its position. While J. Salvege thinks these to be power - or lack thereof - gender and medicalization [15], the International Council of Nurses points out to education, under-funding of health care and a nursing shortage $[4,5]$. All of these factors are closely related.

\subsection{No or limited impact on health policy and health care}

The fact that nurses cannot hold important positions in the health care system limits their full participation in defining action strategies and decision-making within health policy. Nurses in all countries of the world, even those where the health ministry structure includes a nursing department, ${ }^{4}$ have to make every effort to ensure that their opinion on health and health policy is heard. In many countries, the person responsible for nursing at the ministerial, regional and health care level is in fact a doctor. ${ }^{5}$ The involvement of nurses in the health ministry is not only symbolic, but also political, and gives the opportunity for a better position of this professional group in the health care system. Lack of nurses representation among the authorities at the national level also limits their involvement in decision-making in the region, health care and health care teams $[5,15]$.

The many protests organized by nurses in the world point to their low effectiveness in negotiating their position in health care. According to J. Kubisa [16], this is due to the fact that nursing lacks professional status, distinguished by five key attributes that influence the 
power and position of professionals. These include using theory in practice, cultivating the professional authority of the group in the eyes of other social groups, the existence of formal and informal sanctions that impede access to the group, professional ethics and distinctive professional subcultures (professional associations, professional standards, brochures, publications, conferences) [16]. Although nursing has these qualities, they are not recognized by others, including doctors who continue to perceive nurses as auxiliary employees. According to P. Ostrowski, the status of a professional group determines its strength [17].

The position of the occupational group is also influenced by the historical attributes of work, struggle and gender, when access to university education was not only a way of gaining a profession, but also a tool of class exclusion. Since the dominant role in health care was assumed by doctors (due to their higher education, obtaining specialized qualifications), it necessarily marked their influence on the division of labour and its hierarchical value. The dominant role of the physician in health care has been fostered by the established model of health care focused on treatment, and the system of medical education [17].

The way to change the existing situation is to implement interprofessional education (IPE) in medical professions. The idea is to learn together, leading to the formation of mutual respect by getting to know the scope of competence, changing the negative stereotype, and supporting the medical practice where the patient is in the centre of care $[5,7]$. The importance of teamwork and good information flow in the team ensures safety and quality of care $[4,5]$.

\subsection{Feminization of the profession}

Gender is a global problem of nursing. All over the world, the nursing profession is considered to be the most female-dominated job [18]. In Poland, male nurses constitute $1.69 \%$ of all nurses, the lowest indicator in comparison with other countries [2]. In France, the indicator of male nurses amounts to $7.5 \%$, in the Czech Republic $-8.1 \%$, in Hungary $-8.6 \%$ [2]. In Canada and the United States only 5\% of nurses are male [19]. In England and Ireland, men account for $10 \%$ and $4 \%$ of registered nurses, respectively [20]. In other countries of the world, this rate reaches approximately $20 \%$ [21].

The feminization of the profession has led to low wages, low professional status, lack of recognition, bad working conditions, poor career opportunities and inadequate education [18-23], which is confirmed by the results of the jobs ranking published in 2009 by the Wall Street Journal, where the nursing profession was ranked low, taking the $184^{\text {th }}$ position out of 200 . The assessment, which included pay, development prospects and stress, proved the nursing profession to be the least attractive [24].

The low pay of nurses is caused by the fact that women's work is less valued, and they perform care-related tasks, which is associated with poorly paid housework.
In addition, in the public opinion, the nursing job does not involve the specialized skills that are required from the physician [18-23].

The low social status of the profession, low pay, and social stereotype discourage men from choosing the nursing profession [18, 22, 23]. A study conducted by P. Domagała et al. showed a statistically significant result of men and older people more frequently indicating that the nursing profession should be performed by women [22]. Similar results have been reported in other studies where respondents were concerned about care being provided by a man [23].

The low social status of the profession is also noted in practice when the director of hospitals allocates funds for pay rises or while contracting services by the payer. The National Health Fund (Polish NFZ), when signing a contract with health care institutions, requires a certain number of specialists to be provided, while the number of nurses and their qualifications are not taken into account. The implementation of a policy founded on the historically-based class difference, different perceptions of the professional status of physicians and nurses, supported by gender differences (and leading to fact that the feminized profession loses out), causes both occupational groups to miss their common interests. While negotiating with decision makers, trade union and professional representatives point rather to environmental problems, which they consider to be marginalized and addressed with little interest [16].

\subsection{Medicalization of health care}

Medicalization is the process of subjecting life to medical evaluation and control, through defining it in terms of health norms and practices related to the maintenance, restoration and improvement of health $[15,25$, 26]. At the heart of the medicalization process lies the belief that medicine has limitless possibilities in solving health problems, including those unrelated to the real impact of health care. This approach consequently leads to defining social problems such as alcoholism in medical terms, recognizing treatment as proper remedy, and focusing on symptom elimination rather than on the cause when solving health problems [25]. Perceiving nurses as auxiliary medical staff that completes medical goals while underestimating their role in preventive and health promotion activities puts this occupational group in an unenviable position. It is also worth noting that the decision-making in health care at various levels and areas of its organization, made from the perspective of the benefits for 'remedial medicine', is not conducive to implementing a multi-faceted preventive action [5]. Many authors point out that the way to reduce medicalization is to strengthen all primary health care settings in all countries, which is linked to better health and lower cost of care $[5,16]$. In this process, nurses play an important role, mainly in terms of health promotion and problem solving for people with chronic diseases $[4,5,7]$.

The involvement of nurses in primary care is included in the Code of Ethics for Nurses, first adopted by the 
International Council of Nurses (ICN) in 1953, and attributing nurses the responsibility for four basic types of activities: health promotion, disease prevention, health restoration, and bringing relief to the suffering [27]. For years, the World Health Assembly (WHA) has been postulating the need to provide support for nurses to take action to improve the health of individuals, families and the general public. The World Health Organization (WHO) published a report outlining the achievements resulting from several WHA resolutions made to strengthen nursing in the health system. However, the conclusion of the report emphasises a shortage of nurses and their inadequate qualifications, which may constitute restrictions on the provision of health services [7].

\subsection{Financing of health care}

An important factor influencing nursing care are the financial resources. Funding consists of three basic elements: the acquisition of adequate financial resources, elimination of financial barriers to accessing health care, and the best use of available resources. These are the key tools needed to achieve health care goals [7].

In no country in the world is health care funding sufficient, considering the increase in the cost of care due to demographic and non-demographic factors and economic crises. The former group of factors includes the aging population and the associated increase in demand for care, while the latter - wage inflation, cost of medicines, and new technologies related to diagnostics and treatment. The low level of health knowledge also contributes to the increasing cost of care as people with less knowledge about maintaining or recovering health are more likely to be hospitalized and stay in hospital for longer periods of time, achieve worse outcomes, and consequently generate higher costs $[5,6]$.

The OECD report titled 'Health at a Glance 2015' shows that none of the countries, even those with the largest expenditure on health care, achieved the highest rates of quality care. Health expenditures vary, with Poland taking the 36 th position out of 44 countries, with regard to the \% GDP spent. The average per capita expenditure is $\$ 3,453$. Among OECD countries, the largest health care contributor is the United States $-\$ 8,713$, and the lowest India, with \$215. In Poland, we spend an average of $\$ 1,530$, and are followed by Brazil, Costa Rica, Turkey or Colombia - countries that spend even less. The average OECD expenditure on health care amounts to $8.9 \%$ of GDP. Also in this regard, Poland occupies one of the lowest ranking positions, with $6.4 \%$ of GDP spent on health care. For the vast majority of OECD countries, the main source of funding for health care is public expenditure. Only in the United States and Chile, more than $50 \%$ of spending comes from private funds. The average OECD health care spending is as follows: $37 \%$ of 'government' funding, $36 \%$ of social security, $19 \%$ of patients' own contributions, and $6 \%$ of other resources. In Poland, 'government' funding accounts for about $10 \%$ of the expenditure, a significant proportion of which $-61 \%$ - comes from health insurance contributions, and 24\% from patients' own contributions. Most OECD countries have a public health system which grants essential health care. Expenditure on long-term care in OECD countries amounts to $1.7 \%$ of GDP, and $0.4 \%$ in Poland [28].

Although nurses form the largest occupational group among medical professionals, and the costs of nursing care are one of the essential elements of hospital budgets, the problem of processing these costs remains unsolved around the world [4, 5]. Many healthcare systems fail to distinguish nursing care costs from general costs. Proper nurse staffing is an essential element in the development of systems with effective care and rational costs. Studies have shown that the issue of patient prognosis or possible complications generating additional costs is closely related to the quality of nursing care. However, the overall employment and nurse staffing are and will remain to a large extent dependent on the financial resources available to the hospital and accounting for costs, including nursing care costs [7].

In most countries, the diverse costs of nursing care are not considered in hospital budgets, although the intensity of nursing care varies considerably, and there are differences in direct costs of nursing care between the same departments and across different departments $[5,29]$. The intensity of nursing care is the amount of direct and indirect nursing activities necessary for proper care, and factors influencing the level of workload. The intensity of nursing care is closely linked to the workload of nurses, the severity of the patient's condition, and the time spent to provide care to the patient. Only a few countries, such as Denmark, Italy, the Netherlands, Portugal, Spain and the USA, refund the nursing costs to cover the general costs of the so-called board and lodging, without investigating specific aspects of nursing care. This means that the number of hours worked by the nurse is not taken into account. However, the US daily fixed rate principle results in an underestimation of actual nursing costs by 32.2 per cent [30]. Research on the allocation of nursing costs provides the information needed to develop a weighted average for nursing staff in most of the aforementioned countries. Unfortunately, the averaged method does not take into account the variability of nursing workload within Diagnosis Related Groups [31].

In order to provide a detailed description of nursing practice, a number of countries have developed Nursing Minimum Data Sets (NMDS). In Belgium, a 'weight-ofnursing' system is used, based on the Belgian Nursing Minimum Data Sets (B-NMDS), to divide day care into 28 categories for the purpose of allocating budget appropriately, allowing for the varied nurse staffing requirements resulting from the degree of dependency of the patient, the severity of the illness, the complexity of care, and the time needed to provide care. Based on B-NMDS, the standard time for each category of patient classification is determined without the need for time-consuming measurement methods. B-NMDS has a great potential for nursing management systems and resource allocation taking into account nursing workloads [31, 32].

In order to ensure proper involvement of nurses in the financing of health care and nursing workload measure- 
ment, nurse classification systems have been developed. However, these systems are often used only for nursing care and have not come to be widely used [33].

Pursuing its activities, the International Council of Nurses (ICN) has been working on the International Classification for Nursing Practice (ICNP) since 1989. ICNP is a unified nursing language system that enables standardization of nursing documentation in health care settings, enhances communication, information exchange and the use of collected information for other purposes such as: presenting or predicting trends in nursing practice, or allocation of necessary resources [27]. Since 2006 Poland has been working on the implementation of ICNP, which is coordinated by the Polish Nursing Association. ${ }^{6}$

In the Polish System of Diagnosis Related Groups (DRG), in force since 2008, it was assumed that the payer would settle with the hospital on a flat rate basis attributed to the clinically and cost-wise homogenous cases that formed the groups. Unfortunately, cost information from hospitals is not used to evaluate health care services provided by the National Health Fund (NFZ). In fact, the financial resources of the payer are an important factor influencing the value of the DRG. The fund does not even collect and process cost information, although it could be useful in valuing benefits. Estimating DRG costs is usually inaccurate, and the base for pricing is usually the one established in previous years. The system of Diagnostic Related Groups (DRG) based on the American model operates currently in many European countries [34].

The funding patterns with respect to basic health care (Polish: POZ) vary considerably in different countries, which is due to the disparities in the benefits provided under basic health care and lack of a consistent costing methodology, making it difficult to compare this indicator across countries. For example, some countries only pay the fees for primary care practitioners while other include specialist consultations not requiring a referral. The cost of nursing care, mental health promotion, dental care and emergency care may also be included [35].

In Poland, the basis for the implementation of basic health care services (excluding night and holiday health care) is an agreement concluded with the National Health Fund (NFZ). ${ }^{7}$ The funding of social protection benefits depends on annual capitation rates based on the lists of beneficiaries (patients) covered due to submitted declarations, and in the case of children and adolescents, on the basis of the list of pupils provided by schools with which the health care provider has initiated cooperation. For the groups of patients referred to in the contract, the capitation rate is adjusted using the relevant coefficient increasing the funding for benefits. Some counselling and visits within preventive programmes, services provided to non-patients and some sanitary transportation, are funded according to unit prices determined separately for these services [36].

The 2015 annual base capitation rates and the price of services covered by separate funding for basic health care were set out in the regulation of the President of the National Health Fund. ${ }^{8}$ Financing of night and holiday health care services within $P O Z$ is based on a negoti- ated monthly lump sum, and its amount depends on the population living in the protected area. The school nurse/ hygienist contract is concluded with the entities that established cooperation with the director of the school with regard to the preventive care of its pupils, and documented this by submitting a request for a contract with the payer. The services are funded based on the annual capitation rate, taking into account correction coefficients, according to the type of school and pupil (integration classes, sports school, schools with workshops, pupils with disabilities) [36].

In 2015, 6,393 contracts for the provision of basic health care services were signed, with contracts with entrepreneurs $(4,733$ contracts, $74 \%)$ being the greatest in number, followed by contracts with non-entrepreneurs ( 759 contracts, $12 \%)$, individual contracts ( 713 contracts, $11 \%$ ), contracts with sole medical practitioners (188 contracts, 3\%). The forms of contracts are different depending on the form of business and the region it operates in. On a national scale, the lowest number of patients are attended by a nurse who provides services under a contract with a non-entrepreneur $(1,673)$, and the largest within sole medical practice $(1,948)$. POZ nursing services are provided to $35,481,424$ of patients who declared such preference, and whose names are on active lists of $P O Z$ nurses. In 2014, 71,435,417 services were received nationwide (visits, home visits, control visits, treatments, preventive and rehabilitation services). The average number of services in Poland, per 1 patient inscribed on a list of a POZ nurse, is 2.01. This indicator varies in individual voivodeship branches of the National Health Fund (NFZ) - from 1.34 in the Śląskie Voivodeship, up to 3.14 in the Podlaskie Voivodeship. Considering the data on the services provided by $P O Z$ GPs and nurses, it is important to draw attention to fairly significant interdepartmental (regional) disparities in the number of services provided, particularly with regard to nursing care. Looking at the national average, the number of GP services is 2.07 per 1 nursing service [36].

The costs of POZ services in 2015 amounted to PLN 8.8 billion, with the total expenditure on healthcare exceeding PLN 68 billion. Of this amount, about 6.2 billion zlotys were allocated to GP services, 1.2 billion zlotys to nursing care, and about 0.3 billion zlotys to midwives and nurses working in the educational and training environment. In the same period, 5.6 billion zlotys were spent on specialist outpatient care [35].

$P O Z$ nurses can work within their own practice by setting up a business and signing a contract with the National Health Fund or by working for a doctor who provides primary health care. In the latter case, they often provide receptionist or housekeeping services, for example. In 2008, the National Health Fund expanded the requirements for nurses running their own businesses (family nurses), specifying the need to set up their own operatory, open between 8 am and $6 \mathrm{pm}$. National Health Fund justified it by pointing out that many patients using community nursing care do not need it at home. Specifying new requirements for nurses, the National Health Fund did not raise rates for contracts with community 
nurses, which would allow them to rent premises for their operatories and employ an aid. This policy entails that people who are unable to reach the clinic or operatory themselves are denied access to health care [36].

\subsection{Shortage of nurses and working conditions}

The global nursing staff deficit is estimated to be in the range of 22 to $29 \%$ [4, 5, 27]. The shortage of nursing staff affects the functioning of the entire health care system, the availability of care for patients, and has a negative impact on the nursing environment $[4,5]$.

The employment-to-population rate of nurses per 1,000 inhabitants indicates the level of nursing development in a given country and shows the possibilities of ensuring access to care provided by the representatives of this occupational group. The ratio is very different - from 17.6 in Switzerland to 1.1 in Turkey. The OECD average is 9.4, while in Poland this ratio is 5.2, and is higher than the indicator in Turkey (1.1), China (2.2), or Mexico (2.7) [28]. Detailed data is presented in Table $\mathbf{I}$.

The shortage of nurses in the world has become one of the major problems of international institutions [4, 5, $7,27]$. Lack of nurses is associated with prolonged hours of work, workload, excessive stress, fatigue, job dissatisfaction, which has an impact on the quality of care, and is a factor in resigning from work [37-40].

Various international institutions and reliable research findings indicate that the appropriate staffing of nurses is a key element in the development of systems with effective care and rational costs $[4,5,7]$. Studies have shown that the question of prognosis or possible complications in patients that generate additional costs is closely related to the quality of nursing care. However, the overall level of employment and the staffing of nurses depend to a great extent on the financial resources available to the hospital and on cost accounting, including nursing care costs $[5,7]$. Studies completed in 12 European countries ${ }^{9}$ have shown that a significant proportion of nurses are unhappy with their wages, lack of career development and promotion, and are considering leaving the profession. It has been shown that in hospitals where the number of patients per nurse is lower, there is also a lower mortality rate [37-39], and in hospitals with a low number of nurses, many adverse events have been reported (falls, errors in medication administration) [41].

The nursing shortage is caused by health care underinvestment, health care and education reforms, working conditions, low social prestige, migration, decline in interest in vocational training and aging of the occupational group. The average age of nurses is over 40 years, e.g. in Canada - 44.6; the Netherlands - 43.8, Ireland - 41.4, the United Kingdom -42 , Poland -50.79 , and the retirement age in these countries is at least 60 years. In Poland, at the end of 2015, there were 42,206 nurses reaching the retirement age (56-60 years), and 42,451 nurses were over 61 years old, while there were 2,517 registered nurses at the age of 21-35. In the years 2014-2016, 9,854 people completed nursing studies, and 4,021 started work [4]. The presented age structure of nurses indicates that, beside gender, an important factor obstructing nursing care development in the health system will be age. Nurses approaching retirement age working in the health care system will accept the situation of subordination and will not seek greater autonomy. On the other hand, younger, better educated nurses choose jobs with the possibility of their own professional development, less workload and higher wages.

The shortage of nursing staff is deepened by migration, which has been recognized by the World Health Organization (WHO) and the International Council of Nurses (ICN) as a global problem that leads to aggravat-

\begin{tabular}{|l|c|l|c|}
\hline \multicolumn{1}{|c|}{ Country } & Ratio & \multicolumn{1}{c|}{ Country } \\
\hline Austria & 8.0 & Luxembourg & 12.0 \\
\hline Belgium & 10.2 & Mexico & 13.1 \\
\hline China & 2.2 & Germany & 16.7 \\
\hline Czech Republic & 7.9 & Norway & 5.2 \\
\hline Denmark & 16.7 & Poland & 6.1 \\
\hline Estonia & 5.7 & Russia & 8.6 \\
\hline Finland & 14.2 & Slovenia & 17.6 \\
\hline France & 9.7 & Switzerland & 11.1 \\
\hline The Netherlands & 10.5 & Sweden & 8.2 \\
\hline India & 1.4 & Great Britain & 7.8 \\
\hline Irland & 11.9 & Italy & 6.4 \\
\hline Japan & 11.0 & Hungary & 1.9 \\
\hline Canada & 9.8 & Turkey & \\
\hline Lithuania & 7.6 & & \\
\hline
\end{tabular}

Table I. The employment-to-population rate of nurses per 1,000 inhabitants in selected countries. Source: OECD Health Data 2016 - nurses directly employed for patient care, www.stats.oecd.org. 
ing the issue of understaffing in poorer countries. These institutions have asked different governments to take steps to keep their nursing resources in their respective countries through appropriate human resource policies, health care reforms and law regulations fostering positive working conditions. Nurses working in medium and less developed countries emigrate mostly to the United Kingdom, Ireland and the United States, while nurses from more developed countries to Norway and Australia (for example, nurses from Ireland, Great Britain and the USA have emigrated to Australia) [43].

After the accession of Poland to the European Union, nursing and midwifery committees issued a total of 10,202 certificates of recognition for the nursing profession in the Member States, while they granted professional qualifications in Poland to only 41 nurses. In 2016 in Poland, the nursing profession was recognized as a shortage occupation in 13 voivodeships: kujawsko-pomorskie, lubelskie, lubuskie, małopolskie, opolskie, podkarpackie, podlaskie, pomorskie, śląskie, świętokrzyskie, warmińsko-mazurskie, wielkopolskie, zachodniopomorskie [44].

\section{National conditions}

The position of nursing in the Polish health care system is influenced by the abovementioned factors that are present in all countries, and internal factors, including but not limited to: the vocational education system, legal regulations, capability of nurses to impact politicians and health decision makers.

\subsection{Nurse education}

Until the end of the $19^{\text {th }}$ century, nursing in Poland had a charitable and pro-social character. Nursing care was provided by nuns - members of congregations. Nursing was an auxiliary role at that time, and teaching was imparted during courses.

The first modern school was established in 1911 in Cracow as the School of Nursing of the Association of Nurses-Housekeepers of St Vincent de Paul. The school functioned in 1911-1921 (suspended during World War I), becoming a model for the next generation of nurses and contributing to the emergence and development of secular nursing in Poland. The period of 1918-1939 was marked by an intense development of nursing, although nursing care was dominated by nuns, who often lacked qualifications. The main education centres were Cracow, Warsaw and Poznań. American nurses and the International Red Cross were involved in the creation of schools. The development of nursing was connected with hospital development, the establishment of organizational structures (e.g. the Department of Health Service in 1926 at the Ministry of Internal Affairs, the establishment of regional nurses), publication of the magazine titled The Polish Nurse and the inauguration of vocational training [1].

During the Second World War, regular nursing education took place only at the Warsaw School of Nurses and via secret nursing-sanitary courses. During the war, $30 \%$ of nurses died, both in hospitals and military units, during the Warsaw Rising, in ghettos and concentration camps. At the end of the war there were 7 thousand nurses left in Poland, including 2 thousand with full qualifications. Lack of nurses and extensive care needs in society led to the launching of short courses. As a result, the nursing title was given to people with different levels of proficiency. In 1949-1957 people with the title of 'younger nurses' were allowed into the health care system, and were later referred to as nursing assistants. Deficiencies in staffing due to the increase in health needs led to establishing nursing education at medical high schools [1]. In 1990-2005, there were various paths leading to the profession (Table II).

The fact that there was no requirement to have a school-leaving certificate as a condition for starting education at nursing schools and the occupation was not recognized as an autonomous position, situated nurses as auxiliary staff. Poland's integration process with the European Union forced the necessity to take measures to meet the EU requirements, including the mutual recognition of nursing qualifications. In the 1990s, the basis for the transformation of the nursing education system in Poland was the then EU legal framework, including the

\begin{tabular}{|l|l|l|l|l|l|}
\hline \multicolumn{1}{|c|}{ Type of school } & \multicolumn{1}{|c|}{$\begin{array}{c}\text { 5-year medical } \\
\text { secondary school }\end{array}$} & $\begin{array}{c}\text { 2-year medical } \\
\text { vocational school }\end{array}$ & $\begin{array}{c}\text { 2,5-year medical } \\
\text { vocational college }\end{array}$ & $\begin{array}{c}\text { 3-year medical } \\
\text { vocational college }\end{array}$ & \multicolumn{1}{|c|}{$\begin{array}{c}\text { 3-year bachelor } \\
\text { studies }\end{array}$} \\
\hline Education level & $\begin{array}{l}\text { Secondary voca- } \\
\text { tional }\end{array}$ & $\begin{array}{l}\text { Secondary voca- } \\
\text { tional }\end{array}$ & $\begin{array}{l}\text { Secondary voca- } \\
\text { tional }\end{array}$ & $\begin{array}{l}\text { Secondary voca- } \\
\text { tional }\end{array}$ & Tertiary vocational \\
\hline Type of diploma & Nursing diploma & Nursing diploma & Nursing diploma & Nursing diploma & Nursing diploma (BA) \\
\hline Enrolment criteria & $\begin{array}{l}8 \text { years of primary } \\
\text { education }\end{array}$ & $\begin{array}{l}\text { School leaving } \\
\text { certificate }\end{array}$ & $\begin{array}{l}\text { School leaving } \\
\text { certificate (since } \\
1996 \text { 'maturity' } \\
\text { certificate) }\end{array}$ & 'Maturity' certificate & 'Maturity' certificate \\
\hline $\begin{array}{l}\text { Period of receiving } \\
\text { education }\end{array}$ & $1991-1996$ & $1911-1991$ & $1991-2003$ & $1996-1999$ & $\begin{array}{l}\text { 1998 UJ CM Cracow, } \\
\text { Poland since 2000 }\end{array}$ \\
\hline
\end{tabular}

Table II. Paths leading to the nursing profession, 1990-2005.

Source: Kózka M., Efektywność kształcenia zawodowego pielęgniarek na studiach pierwszego stopnia w okresie transformacji systemu edukacji, Uniwersyteckie Wydawnictwo Medyczne „, Vesalius”, Kraków 2008, p. 30. 
European Agreement on the Instruction and Education of Nurses drawn up in Strasbourg in 1967, and signed by the Government of the Republic of Poland in December 1995, ratified in March $1996^{10}$ [45]. By ratifying this regulation, the Government committed itself to keeping the standard of nursing education starting from the year 2000, which included:

1) nurse's tasks: providing care to the individual and family in health, sickness and disability; co-operation with all members of health care teams; supervision of auxiliary staff and responsibility for their training;

2) school enrolment requirements: completion of at least 10 years of general education and a school-leaving certificate;

3) length and programme of education: the duration of education must be at least 3 years and the programme shall cover 4,600 hours of vocational training, of which half shall be devoted to practical training [45]. Nurse qualifications in the European Union are recognized under the Directive 2005/36 EC of the European Parliament and of the Council of 7 September 2005, ${ }^{11}$ amended on 20 November 2013. ${ }^{12}$

Currently, higher nursing education is available at 84 higher education institutions (universities, academies and vocational colleges). Nurses can gain professional qualifications at bachelor and master degree levels, and have the opportunity to undertake doctoral studies and various forms of postgraduate courses [45]. The first forms of nurses training in Poland were initiated in 1960, and focused on the training of nursing teachers, later postgraduate training was conducted in the form of training, qualification and improvement courses. It was not until the 1980s that nurses were given the opportunity to undertake specialist courses. Currently, nurses are required to complete postgraduate training as part of specialized courses, qualification courses, specialization in various fields of nursing, and refresher courses. ${ }^{13}$ Despite the high involvement of nurses in the field of post-graduate education, the scope of qualifications remains poorly defined, limiting the possibility of promotion [2].

\subsection{Legal requirements}

The legal status and rules for pursuing the nursing profession were regulated for the first time in the Nursing Act of 21 February $1935 .{ }^{14}$ It introduced a uniform definition of the concept of 'nursing practice', as well as the criteria of nursing education and profession. According to the Act, nursing practice was understood as: providing care to patients in medical institutions and private homes, executing physician's orders for the sick, working at medical institutions, preventive institutions, care institutions, social institutions, schools, industrial plants and private homes regarding general and personal hygiene promotion, combating epidemics and preventing diseases. The practice of nursing was supervised by the Minister of Social Welfare. The law was in force for 61 years [1]. Changes in the political system allowed for a professional association to be established in 1991 under the Nursing and Midwifery Act. ${ }^{15}$ The law was amended in 2011. ${ }^{16}$ Undoubtedly, the most important event for the nursing profession - posterior to the system transformation - occurred on 5 July, 1996, the day the Nursing and Midwifery Act was approved, replacing the previous nursing act of 1935 and the regulation of the President of the Republic of 16 March 1928 on midwifery [1]. The act was amended several times, and finally on 15 July, 2011 the new law was adopted. According to Article 2 of the Act of 5 July 1996, the nursing profession is autonomous. The scope of autonomy was legally regulated for the first time by the Regulation of the Minister of Health and Social Welfare dated 2 September $1997 .{ }^{17}$ The legal regulations significantly changed the position of the nurse within the system, who gained full autonomy in fulfilling their duties and became a full member of the health care team. Obtaining legal autonomy means that the nurse is independent (autonomous) of other professionals in nursing care, interdependent in issues related to health promotion, prevention and rehabilitation, and dependent on the physician in issues related to treatment. When performing doctor's instruction (not orders - as referred to previously - which excluded the possibility of questioning their fairness and taking responsibility even when they were objectively wrong), the nurse carries out their duties as a member of the team, cooperating and participating in the treatment process. In addition, the nurse may refuse to perform the physician's order in situations specified in the law.

In addition to gaining autonomy, a significant change in the new legal regulation is the provision relating to the liability of the nurse. In the 1935 Act, the nurse was liable to the person who ordered them to perform the act (i.e. to the doctor), but according to the current law the nurse is liable to the recipient of the act (i.e. the patient). In the new law, the nurse is entitled to legal protection equal to that provided to any other public official. Earlier legislation did not protect the nursing profession likewise [1].

\subsection{Scope of leadership}

The scope and strength of leadership in nursing at the national level and that of individual health care facilities is important for how nursing is situated in the health care system $[5,16,44,46]$. In the leadership debate, two areas were defined: formal and legal, and actual. With regard to the former (i.e. the act on health care provision, the act on professional association and midwifery, on nursing and midwifery professions, on patient rights and the $\mathrm{Pa}$ tient Rights Ombudsman, on health care consultants, the Minister of Health regulation on qualifications required from employees at individual workplaces in non-entrepreneurial health care entities), nursing takes up a high position in the Polish system. Nursing is an autonomous profession with decision-making powers and liable for the activities connected with providing patient care [2]. The Nursing and Midwifery Act states that these professions are autonomous, with decision-making powers and liable for the activities connected with providing patient care, managing the nursing services sector, nursing and midwifery training, conducting research, performing 
work in health care institutions, public administration organs supervising health care, as well as military and prison services, employment in social welfare homes, day nurseries, children's after-school clubs, and being elected as part of local authorities and trade unions. Nurses can be self-employed and work as entrepreneurs by organizing individual, group or specialized nursing practice and health care institutions ( $Z O Z)[2]$.

According to the act on professional associations, nurses have a well-developed self-governmental organizational structure, supervising the profession, issuing opinions on all draft laws and regulations concerning education, training and professional practice. Professional association also elaborates various reports on staffing resources in nursing, care needs, self-employment, education and professional development. In addition, it represents the interests of this profession in the Parliament and ministries as well as creates the image of nurses by organizing conferences attended by the media, parliamentarians and other professional groups. Another formal and legal body is the Nursing and Midwifery Department at the Ministry of Health. Its director and staff have a formal influence on the final form of legal acts and documents concerning nursing practice, and pregraduate and post-graduate training. They cooperate with professional associations, nursing consultants, academic societies, nursing education institutions and the National Accreditation Council for Nurses and Midwifery Schools (Polish: KRASZPiP).

An important step in strengthening the position of nursing among medical professions was the appointment of national and voivodeship consultants in various fields of nursing in 2002. ${ }^{18}$ The consultants advise the Minister of Health and voivodes on nursing practice as well as training, supervise the nursing practice within their specialty, control the implementation of good practices in the nursing sector, and make changes to improve the quality of care.

In the international arena nursing is represented by the Polish Nursing Association (PTP), which is a permanent member of the International Council of Nurses (ICN) and the European Federation of Nurses Associations (EFN). Its representatives apply in their own countries those solutions that proved successful abroad, such as the International Classification for Nursing Practice (ICNP).

The presented formal and legal scope of leadership in nursing is undoubtedly an important element of building the position, autonomy and prestige of the nursing profession in Poland. However, the real scope of leadership, including the influence of nursing managers in health care facilities, and so the practice of nursing, differs significantly from the formal and legal scope [46].

The area of research and pre- and post-graduate education is in fact the broadest and most independent. Nurses are involved in the development of education and training programmes, they are members of the committee overseeing the quality of education imparted at universities, and carry out individual or team research.

The real leadership scope in managing nursing care and nursing practice is much smaller than it seems looking at the formal and legal regulations. The cause of this is the poor preparation for nursing management among people in directorial positions (deputy head of nursing / chief nurses, nurse managers and senior nurses), the unfavourable position of the above mentioned managerial positions in the organizational structure of the hospital, and lack of clearly defined powers. Formally, the deputy head of nursing/chief nurse is an equal position to that of the deputy head of health care. However, in practice, the most important nursing decisions are made by the manager of the institution or the deputy health care. Similarly, the senior nurse is more commonly liable to the chief doctor of the ward rather than the head nurse or nurse manager. The nursing staff does not have an independent budget for nursing care and the final vote on human resources issues, payroll, postgraduate training, and equipment supplies is given to the manager of the institution or chief doctor. This also applies to the choice of care method and often the division of nurses' work. The fact that the nursing managerial staff lacks precisely delineated responsibilities with regard to nursing management, and it takes an ambiguous position in hospitals concerning nursing-related decisions, translates into what is required of unit nurses regarding nursing care provided for a patient. Although most hospital regulations define the responsibilities, powers and duties of nurses, the actual hierarchy of performing duties and its accounting is different than the formal regulation [46]. As numerous studies on the type of activities performed by nurses in Polish hospitals show, they mostly perform diagnostic and therapeutic tasks upon doctor's instruction [45, 49]. These tasks are also carefully documented. This is due to the strong position of doctors in hospital wards and the fact that only this area of nursing activity is of interest to them. Nursing care tasks that include support while feeding, hygiene, rehabilitation, excretion, etc., and psychological support, providing information and education to the patient and their family, are performed less frequently and less willingly $[47,48]$. Psychological support, especially patient education, are also not realized according to the needs of patients, as doctors are reluctant to patients being imparted information by nurses. Senior nurses monitor unit nurses more willingly by looking at measurable (diagnostic and therapeutic) activities than the support and education provided. It should be noted, however, that such hierarchy in the performance of tasks is not only due to the weak position of the senior nurse or the reluctance of nurses to provide complete care, but to a large extent to the shortage of nurses on duty [45].

\section{Summary and conclusions}

The nursing profession is an autonomous medical profession, subject to regulations and requiring continuous training and improvement, which includes fulfilling roles that result from the professional functions defined by the WHO (providing care and care management, education, cooperation in health care teams, personal and professional development).

Currently, a nurse is required to obtain professional qualifications at the higher education level and be pre- 
pared to perform health care services, in particular: recognizing the patient's condition and health needs; recognizing patient care issues; planning and providing care for the patient; independent provision of certain preventive, diagnostic, therapeutic and rehabilitation services and medical emergency services; execution of medical instruction in the diagnostic and treatment process; deciding on the type and scope of health care services; health education and health promotion. In addition, the nursing profession includes training nursing staff, professional development efforts, nursing research and the management of the nursing team.

The development of Polish nursing and its position in the health care system has been influenced by many of the factors mentioned in this article. The subject needs further analysis as it is important both for the professional group and the functioning of the entire health care system.

The basic problem of nursing in Poland today is the increasing shortage of nurses. The current number of nurses employed in the health care system is not sufficient to provide optimal care, and the worrying forecasts make the future look bleak. The current problems of the nursing environment include: wages inadequate to the education received, insufficient number of nurses trained (with respect to those reaching retirement age), degrees of roles and responsibilities fulfilled, high workloads (lack of auxiliary staff) as well as lack of valuation and funding of nursing care. Addressing these issues requires action at the governmental level, including funding from the state budget. Choosing a different solution will be a source of conflict with other medical professionals, who will point out to nurses as a group that strives to meet their own needs.

\section{Notes}

1 The International Council of Nursing (ICN) is a federation of 135 national nursing associations representing millions of nurses around the world. The organization is directed by nurses and for nurses, speaks out on their behalf in the international arena and ensures the provision of quality care for all as well as the development of good health policies at a global level.

2 The Act on Nursing and Midwifery Professions of 5 July, 1996 ("Journal of Laws" 1996; 91: 410), as amended, and the later Act on Nursing and Midwifery Professions of 15 July 2011 ("Journal of Laws" 2011; 174: 1039) as amended.

${ }^{3}$ In Poland, nurses were granted the right to issue prescriptions starting from 1 January 2016 in accordance with the Ordinance of the Minister of Health of 28 October 2015 ("Journal of Laws" 2015; 1971) based on the Act 15a (8), 3-6 of 15 July 2011 on the Nursing and Midwifery Professions ("Journal of Laws" 2014; 1435), as amended.

${ }^{4}$ In Poland, the Department of Nursing and Midwifery was established in 2005 and is in fact managed by a nurse.

${ }^{5}$ In Poland it was only in February 2017 that the position of Undersecretary of State in the Ministry of Health was granted to nurse Józefa Szczurek-Żelazko.

${ }^{6}$ In 2010, the International Council of Nurses established the Accredited ICNP Research and Development Centre in Po- land, which operates at the Faculty of Health Sciences of the Medical University of Łódź. The aim is to educate nurses about conducting research and putting it into ICNP practice.

7 Art. 159 of the Act of 27 August 2004 on publicly-funded health care services ("Journal of Laws" 2015; 581, as amended).

${ }^{8}$ Annex No. 1 to the Regulation No. 3/2014 / DSOZ of the President of the National Health Fund, dated 7 January 2015.

${ }^{9}$ In 2009-2012, the European HEALTH-F2-2009-223468 grant programme titled 'Nurse Forecasting: Human Resources Planning in Nursing' (RN4CAST) was implemented in 12 countries, including Poland, represented by the Institute of Nursing and Midwifery of the Faculty of Health Sciences UJ CM.

10 "Journal of Laws" 1996; 83: 3884, 385.

11 "EU Journal of Laws" 2005; L255/24.

12 "EU Journal of Laws" 2013; L354/132.

${ }_{13}$ Regulation of the Minister of Health of 29 October 2003 on postgraduate nursing and midwifery education ("Journal of Laws" of 21 November 2003) and the Regulation of the Minister of Health of 12 December 2013 that became binding on 24 August 2015, included the areas of nursing and the areas relevant to health care in which specialization and qualification courses may be conducted ("Journal of Laws" of 16 December 2013).

14 Act of 21 February 1935 on Nursing ("Journal of Laws" 1935; 27: 199).

15 Act of 19 April 1991 on nurses and midwives' professional association ("Journal of Laws" 1991; 41: 178, as amended).

16 Act of 1 July 2011 on nurses and midwives' professional association (“Journal of Laws" 2011; 174: 1038).

${ }^{17}$ Regulation of the Minister of Health and Social Welfare of 2 September 1997 on the type and scope of preventive, diagnostic, prophylactic and treatment care performed by a nurse independently of a doctor's order ("Journal of Laws" 1997; 118: 750 as amended) and the revised Regulation of the Minister of Health of 28 February 2017 ("Journal of Laws" 2017; 0: 497).

18 Act on health care consultants of 6 November 2008 ("Journal of Laws" 2008; 52: 419, as amended).

\section{References}

1. Slosorz T., Ksztatcenie zawodowe pielegniarek $w$ ujęciu historycznym, „Przegląd Nauk o Zdrowiu” 2014; 4 (41): 298-304.

2. Naczelna Izba Pielęgniarek i Położnych, Zabezpieczenie społeczeństwa polskiego w świadczenia pielegniarek i położnych, Raport Naczelnej Rady Pielęgniarek i Położnych, Warszawa 2017.

3. Bajtor A., The importance of social and cultural factors to nursing status, "Int. J. Nurs. Pract.” 2003; 9: 328-335.

4. Interantional Council of Nursing, Nurses, Pielegniarki sa siła na rzecz zmian, Efektywna opieka i racjonalne koszty, ICN, Geneva 2015, www.ptp.na1.pl/pliki/ICN/20150909_ ICN_Pielegniarki_sa_sila_na_rzecz_zmian.pdf (accessed: 12.07.2017).

5. International Council of Nursing, Nurses, Pielegniarki sita na rzecz zmian, kluczowymi zasobami na rzecz zdrowia, ICN, Geneva 2014, www.ptp.na1.pl/pliki/ICN/ICN_Pielegniarki_sa_sila_2014.pdf (accessed: 06.06.2017).

6. International Council of Nurses and the World Bank, Strengthening Community and Frontline Health Work- 
ers for Universal Health Coverage, ICN, Geneva 2014, www.nurse.or.jp/nursing/international/icn/report/ pdf/2014m/08-06.pdf (accessed: 10.06.2017).

7. World Health Organization, Strategic Directions for Strengthening Nursing and Midwifery Services 2011-2015, 2010d,ww.who.int/hrh/nursing_midwifery/en/(accessed: 05.06.2017).

8. Reeves S., Zwarenstein M., Goldman J., Barr H., Freeth D, Hammick M, Koppel I., Interprofessional education: effects on professional practice and health care outcomes, "Cochrane Database of Systematic Reviews" 2008; 1.

9. Keogh B., Review into the quality of care and treatment provided by 14 hospital trusts in England, overview report, 2013, https://www.nhs.uk/nhsengland/bruce-keogh-review/ documents/pdf (accessed: 07.2017).

10. www.oecd.org/officialdocuments/publicdisplaydocumentpd $\mathrm{f} /$ ?cote $=\mathrm{delsa} / \mathrm{hea} / \mathrm{wd} / \mathrm{hwp} \% 282010 \% 295 \&$ doclanguage $=$ en (accessed: 14.04.2017).

11. Organisation for Economic Co-operation and Development, Nurses in advanced roles, A description and evaluation of experience in 12 developed countries, 2010,

12. The Joanna Briggss Institute Best Practice Information Sheet, Nurse-led intervention to reduce cardiac risk factor in adults, "Nursing and Health Sciences" 2010; 12: 288-292.

13. International Council of Nursing, Position statement on Participation of nurses in health service decision - making and policy development, www.icn.ch/images/stories/ documents/publications/position_statements/D04_Parcticipation_Decision_making_Policy_Development.pdf (accessed: 02.05.2017).

14. Kringos D.S., Boerma W. van der Zee J., Groenewegen P., Europe's strong primary care systems are linked to better population health but also to higher health spending, "Health Affairs" 2013; 32 (4): 686-694.

15. Masseria C., Irwin R., Thomson S., Gemmill M., Mossialos E., Primary care in Europe. Policy brief for the European Commission Directorate-General, "Employment, Social Affairs and Equal Opportunities" 2009; Unit E1 - Social and Demographic Analysis December 2009, London School of Economics and Political Science, file:///H:/RN2009_Primary\%20care.pdf (accessed: 14.04.2017).

16. Salvage J., Pieleggniarstwo $w$ działaniu, Publikacje regionalne WHO, Seria Europejska Nr 48, Warszawa 1998.

17. Kubisa J., Protesty pieleggniarek i położnych $w$ kontekście reform ochrony zdrowia, 2009; 3, Biblioteka Online Think Thanku Feministycznego, www.ekologiasztuka.pl./ pdf/f0086_TIFraport3_Pielegnarki-Kubisa.pdf (accessed: 08.06.2017).

18. Ostrowski P., Deregulacja rynkowa w procesie reformy ochrony zdrowia a protesty pielęgniarek i położnych, w: Kozek W. (ed.), Instytucjonalizacja stosunków pracy w Polsce, Wydawnictwo Naukowe Scholar, Warszawa 2003.

19. Mullan B., Harrison J., Male and female nursing applicants' attitudes and expectations towards their future careers in nursing, "J. Res. Nurs." 2008; 13 (6): 527-539.

20. Keogh B, O’Lynn C., Male nurses' experiences of gender barriers: Irish and American perspectives, "Nurse Educ." 2007; 32 (6): 256-259.

21. Muldoon O.T., Reilly J., Career choice in nursing students: gendered constructs as psychological barriers, "J. Adv. Nurs." 2003; 43 (1): 93-100.
22. Zabielska P., Bażydło M., Karakiewicz A., Grochans E., Jurczak A., Rotter I., Nurses' Health in Shift Work, "Journal of Public Health. Nursing and Medical Rescue" 2014; 2: 14-17.

23. Domagała P., Kretowicz K., Żuralska R., Percepcja mężczyzn wykonujących zawód pielęgniarza w spoleczeństwie, "Problemy Pielęgniarstwa" 2013; 21 (4): 462-470.

24. Dudak A., Wybrane aspekty funkcjonowania mężczyzn $w$ zawodach sfeminizowanych, "Problemy Profesjologii" 2016; 2: 24-32.

25. The Best and Worst Jobs in the US-WSJ, http://online.wsj. com/news/articles/SB123119236117055127 (accessed: 30.09.2017).

26. Kłos J., Gromadecka-Sutkiewicz M., Zysnarska M., Medykalizacja-wyzwania XXI wieku, "Hygeia Public Health" 2014; 49 (3): 382-388.

27. Conrad, P., Mackie T., Mehrotra A., Estimating the costs of medicalization, "Social Science \& Medicine" 2010; 70 (12): 1943-1947

28. International Council of Nurses, ICN Fact Sheet on Positive Practice Environments, 2013, www.icn.ch/images/stories/ documents/publications/fact_sheets/9d_FS-Positive_Practice_Environments.pdf. (accessed: 16.07.2017).

29. Raport OECD, Health at Glance 2015, www.oecd.org (accessed: 16.07.2017).

30. Welton J.M., Fischer M.H., DeGrace S., Zone-Smith L., Hospital nursing costs, billing, and reimbursement, "Nurs. Econ." 2006; 24 (5): 239-245.

31. Laport N., Sermeus W., Vanden Boer G., Van Herk P., Adjusting for nursing case mix in hospital reimbursement: a review of international practice, "Policy Politics and Nursing Practice" 2008; 9 (2): 94-102.

32. Sermeus W., Delesie L., Van den Heede K., Diya L., Lesaffre E., Measuring the intensity of nursing care: Making use of the Belgian Nursing Minimum Data Set., "International Journal of Nursing Studies" 2008; 45 (7): 1011-1021.

33. Sermeus W., Gillet G., Gillain D., Grietens J., Laport N., Michiels D., Thonon O., Vanden Boer G., Van Herck P., Van den Heede K., Development and validation of nursing resource weights for the Belgian Nursing Minimum Dataset in general hospitals: A Delphi questionnaire survey approach, "International Journal of Nursing Studies" 2009; 46 (2): 256-267.

34. Ślusarska B., Implementacja wybranych klasyfikacji diagnoz i interwencji pielegniarskich dla praktyki pielęgniarstwa polskiego, "Zeszyty Naukowe. Zdrowie Publiczne i Zarządzanie" 2016; 14 (1): 11-22.

35. Sobiech J., System jednorodnych grup pacjentów jako mechanizm finansowania szpitala, w: Rój J., Sobiech J. (ed.), Zarządzanie finansami szpitala, Wolters Kluwer, Warszawa 2006.

36. Groenewegen P.P., Strengthening weak primary care systems: Steps towards stronger primary care in selected western and eastern European countries, "Health Policy" 2013; 113 (1): 170-179.

37. Krytyczna analiza funkcjonowania podstawowej opieki zdrowotnej $w$ Polsce, Warszawa 2016, oipip.elblag.pl/ wp-content/uploads/2015/.../Krytyczna-analiza-POZ-8-czer-2016-1.pdf (accessed: 30.09.2017).

38. Aiken L.H., Clarke S.P., Sloane D.M., Lake E.T., Cheney $\mathrm{T}$., Effects of hospital care environment on patient mortality 
and nurse outcomes, "Journal of Nursing Administration" 2008; 38 (5): 223-229.

39. Aiken L.H., Douglas M.S., Bruyneel L., Van de Heede K., Sermeus W., Nurses' reports of working conditions and hospital quality of care in 12 countries in Europe, "International Journal of Nursing Studies" 2013; 50: 143-153.

40. Aiken L.H., Sloane D.M., Bruyneel L., Van den Heede K., Griffiths P., Busse R., Diodidous M., Kinnunen J., Kózka M., Lesaffre E., McHugh M.D., Moreno Casbas M.T., Rafferty A.M., Schwendimann R., Scott P.A., Tishelman C., van Achterberg T., Sermeus W., Nurse staffing and education and hospital mortality in nine European countries: A retrospective observational study, "The Lancet" 2014; 383 (9931): 1824-1830.

41. Heinen M.M., Achterberg T., Schwendimann R., Zander B., Matthews A., Kózka M, Ensio E., Sjetne I.S., Moreno Casbas T., Ball J., Schoonhoven L., Nurses' intention to leave their profession: A cross sectional observational study in 10 European countries, "International Journal Nursing Studies" 2012, Oct 26, pii: S0020-7489(12)00330-6. doi: 10.1016/j.ijnurstu.2012.09.019.

42. Duffield C., Diers D., O'Brien-Pallas L., Aisbett C., Roche M., King M., Aisbett K., Nursing staffing, nursing workload, the work environment and patient outcomes, "Applied Nursing Research" 2011; 24 (4): 244-255.

43. Buchan J., Parkin T., Sochalski J., International nurse mobility. Trends and policy implications, Bulletin of the WHO, Geneva 2003.
44. Barometr Zawodów, Wojewódzkie Urzędy Pracy, www. barometrzawodow.pl (accessed: 01.10.2017).

45. Kózka M., Efektywność ksztatcenia zawodowego pielęgniarek na studiach pierwszego stopnia w okresie transformacji systemu edukacji, Uniwersyteckie Wydawnictwo Medyczne „Vesalius”, Kraków 2008.

46. Kózka M., Brzostek T., Ksykiewicz-Dorota A., Analysis of nurse staffing and factors determining the demand for health care in Poland, "Prog. Health Sci." 2011; 1, 2: 5966.

47. Ksykiewicz-Dorota A., Zarządzanie w pielegniarstwie, Wydawnictwo PZWL, Warszawa 2013.

48. Gabryś T., Kózka M., Brzyski P., Kózka M., Brzostek T., Gabryś T., Brzyski P., Ogarek M., Cisek M., Przewoźniak L., Ksykiewicz-Dorota A., Gajda K., Wybrane czynniki determinujace ocenę jakości opieki pielęgniarskiej w szpitalach petniacych staty dyżur. Wyniki projektu RN4CAST, "Zeszyty Naukowe Ochrony Zdrowia. Zdrowie Publiczne i Zarządzanie" 2012; 10 (B): 278-288, 2012; 10 (4): 267277.

49. Cisek M., Przewoźniak L., Kózka M., Brzostek T., Brzyski P., Ogarek M., Gabryś T., Gajda K., Obciażenie praca podczas ostatniego dyżuru $w$ opinii pielęgniarek pracujacych w szpitalach objętych projektem RN4CAST, "Zeszyty Naukowe Ochrony Zdrowia. Zdrowie Publiczne i Zarządzanie" 2013; 11 (2): 210-224. 